\title{
Salt Effects on Plastein Formation by $\alpha$-Chymotrypsin
}

\author{
Shin-ya Tanimoto, Michiko Yamashita, Soichi Arai \\ and Masao FUJIMAKI \\ Department of Agricultural Chemistry, University of Tokyo, Tokyo \\ Received October 30, 1974
}

\begin{abstract}
The plastein formation by $\alpha$-chymotrypsin from an ovalbumin hydrolysate was affected in an order of valency of salts when the concentration of each salt was $1 \mathrm{M}$. Monovalent cations were rather effective at this concentration and enhanced the plastein yield by $10 \%$. In the presence of $\mathrm{NaCl}$, the plastein formation showed two distinct maximal rates at its concentrations of $0.1 \mathrm{M}$ and $0.8 \mathrm{M}$. The first maximum was considered to be resulted from an increase in enzyme activity, since chymotryptic hydrolysis of both $N$-acetyl-L-tyrosine ethyl ester and benzyloxycarbonyl-L-phenylalanine $p$-nitrophenyl ester was activated at an $\mathrm{NaCl}$ concentration of $0.1 \sim 0.2 \mathrm{M}$. The second maximum was ascribed to the salting-out of the product due to the higher concentration of $\mathrm{NaCl}$. A salt-tolerant protease was also used to confirm the above conclusions. It was observed that this enzyme was much effective in producing a plastein at a high $\mathrm{NaCl}$ concentration. This may be due to the fact that both the enzyme activation effect and the product salting-out effect participate co-operatively.
\end{abstract}

A main mode of $\alpha$-chymotrypsin in the plastein reaction has been proposed. ${ }^{1,2)}$ Several reports have been presented concerning the reaction conditions such as effects of

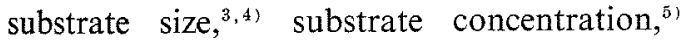
and $\mathrm{pH}^{6}{ }^{6}$ Besides these, a salt effect is considered to be important to study, especially from the standpoint of practical application of the plastein reaction. At least two effects are expectable from such a study. One is an effect of salt on enzyme activation or inactivation during the reaction and the other is its effect on salting-out of the product. If the latter factor is involved, the product is eliminated from the system by being salted out and accordingly the reverse reaction proceeds efficiently. This may be expected to have practical use in producing a plastein in a higher yield.

The present study investigates such salt effects to provide basic information to achieve the practical purpose mentioned above.

\section{MATERIALS AND METHODS}

Substrates. An ovalbumin preparation (20 g) from DIFCO was dissolved in $0.5 \mathrm{~N} \mathrm{NaOH}(400 \mathrm{ml})$ and the solution was centrifuged at $5000 \mathrm{rpm}$ for $20 \mathrm{~min}$. The supernatant was dialyzed through a cellophane membrane against running water for 2 days and against deionized water (10 liters) at $4^{\circ} \mathrm{C}$ for the following 2 days. This desalted ovalbumin solution was diluted to 2 liters with deionized water and incubated with $200 \mathrm{mg}$ of subtilisin BPN' (Nagase Sangyo Co.) at $37^{\circ} \mathrm{C}$ for $24 \mathrm{hr}$. The hydrolysate was dialyzed through a cellophane membrane against deionized water (10 liters) at $4^{\circ} \mathrm{C}$ for 2 days to obtain a dialyzable fraction. This was freeze-dried and the resulting powder was used as a substrate for the plastein reaction. The following two amino acid derivatives were used for comparison: $\mathrm{N}$-acetyl-L-tyrosine ethyl ester (ATEE) obtained from Kanto Kagaku Co. and carbobenzyloxyL-phenylalanine $p$-nitrophenyl ester (Z-Phe-PNP) synthesized by the method of Bodanszky and Vigneaud. ${ }^{\text {?) }}$

Enzymes. $\alpha$-Chymotrypsin (Miles Servac) and a salt-tolerant, neutral protease (tentatively named Neutral Protease II) from Aspergillus sojae ${ }^{81}$ were used.

Determination of synthetic activity. A substrate solution was prepared by dissolving the ovalbumin hydrolysate (dialyzable fraction) in deionized water to a concentration of $35 \%(\mathrm{w} / \mathrm{v})$. The $\mathrm{pH}$ was adjusted to 6.6. The enzyme-substrate ratio was set at $1 / 100$ (w/w) and the reaction temperature at $37^{\circ} \mathrm{C}$. In using Neutral Protease II the enzyme-substrate ratio was chosen as $1 / 3(\mathrm{w} / \mathrm{w})$. The reaction time was set at $2 \mathrm{hr}$ because a linear time-response relation was obtained from a preliminary experiment. Furthermore, a relative activity $V / V_{0}$ was expressed as a ratio between a reaction rate in a given salt solution and that in dei- 
onized water.

Determination of hydrolytic activity. Degree of hydrolysis of $\mathrm{N}$-acetyl-L-tyrosine ethyl ester and carbobenzyloxy-L-phenylalanine $p$-nitrophenyl ester were determined according to the decrease in the optical density at $237 \mathrm{~nm}^{9}$ and to the increase in the optical density at $\left.402 \mathrm{~nm},{ }^{10}\right)$ respectively. The relative activity $V / V_{0}$ was obtained similarly. More detailed description on the experimental procedures and the hydrolysis conditions is given in the legend to Fig. 2.

Determination of solubility. To an $\mathrm{NaCl}$ solution ( $1 \mathrm{ml}$ ) was added $\alpha$-chymotrypsin and its solubility was determined by the turbidometric method described in a previous paper. ${ }^{3)}$ To an $\mathrm{NaCl}$ solution $(5 \mathrm{ml})$ was added a freeze-dried plastein $(25 \mathrm{mg})$ to determine its solubility similarly.

\section{RESULTS}

\section{Effects of salts on plastein formation}

When each of various salts was added to a reaction system in a concentration of $1 \mathrm{M}$, the plastein productivity was affected as the salt charge increased (Table I). In this case mono-monovalent salts, $\mathrm{LiCl}, \mathrm{NaCl}$ and $\mathrm{KCl}$, had a rather favorable effect and the plastein productivity was enhanced by about $10 \%$ in each case (Table I).

Table I. Effects of Salts on Plastein ProductivtTy of $\alpha$-CHYMOTRYPSIN

\begin{tabular}{lcc}
\hline \multicolumn{1}{c}{ Salt } & $\begin{array}{c}\text { Ionic strength in } \\
\text { the reaction system }\end{array}$ & $\begin{array}{c}\text { Plastein pro- } \\
\text { ductivity } V / V_{0}\end{array}$ \\
\hline $\mathrm{LiCl}$ & 1 & 1.12 \\
$\mathrm{NaCl}$ & 1 & 1.12 \\
$\mathrm{KCl}$ & 1 & 1.13 \\
$\mathrm{MgCl}$ & 3 & 0.80 \\
$\mathrm{CaCl}_{2}$ & 3 & 0.65 \\
$\mathrm{CoCl}_{2}$ & 3 & 0.15 \\
$\mathrm{ZnCl}_{2}$ & 3 & 0.15 \\
$\mathrm{AlCl}$ & 6 & 0.17 \\
$\mathrm{FeCl}_{3}$ & 6 & 0.05 \\
$\mathrm{NaNO}_{3}$ & 1 & 1.01 \\
$\mathrm{NaNO}_{2}$ & 1 & 1.01 \\
$\left.\mathrm{CH}_{3} \mathrm{COONa}^{a}\right)$ & 1 & 0.75 \\
$\mathrm{Na}_{2} \mathrm{SO}_{4}$ & 3 & 1.01 \\
$\mathrm{Na}_{2} \mathrm{SO}_{3}$ & 3 & 0.86 \\
$\mathrm{Na}_{3} \mathrm{PO}_{4}{ }^{\alpha}$ & 6 & 0.81 \\
\hline
\end{tabular}

a) In each reaction $\mathrm{pH}$ was adjusted to 6.6 with $\mathrm{NaOH}$ or $\mathrm{HCl}$.

The dependunce of the plastein produc- tivity on the salt concentration was investigated with $\mathrm{NaCl}$ and the plastein productivity plotted as a function of ionic strength showed two maxima at 0.1 and at 0.8 (Fig. 1).

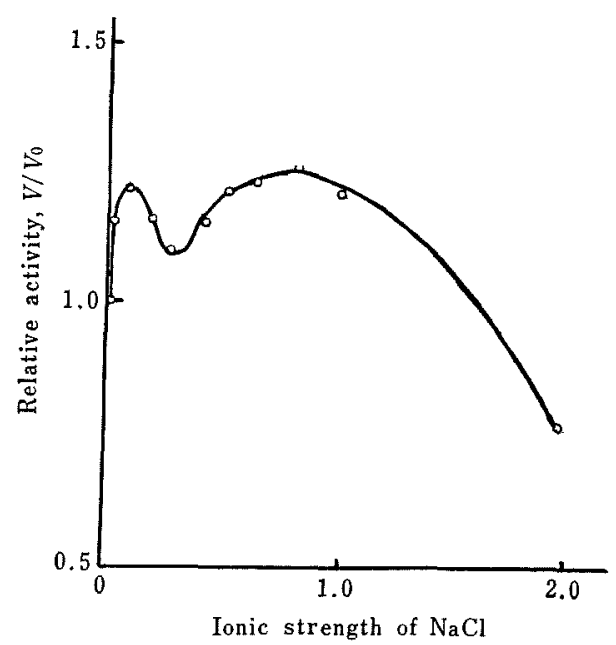

FIG. 1. Plastein Productivity as a Function of Ionic Strength of $\mathrm{NaCl}$.

Effect of $\mathrm{NaCl}$ upon the hydrolytic activity of $\alpha$-chymotrypsin

$\alpha$-Chymotryptic hydrolysis of ATEE was investigated under a usual condition and of Z-Phe-PNP under such a condition as approximated to that for the plastein reaction. The ATEE hydrolyzability showed a maximum at ionic strength of 0.3 . There was a maximum at ionic strength of 0.2 in hydrolysis of ZPhe-PNP. In both cases the hydrolytic activities of $\alpha$-chymotrypsin decreased as this enzyme was salted-out by $\mathrm{NaCl}$ (Fig. 2).

\section{Salting-out effect of $\mathrm{NaCl}$ upon plastein}

Solubilities of a plastein at various $\mathrm{NaCl}$ concentrations are shown in Fig. 3. From this result it is estimated that the plastein is salted-in at ionic strength of about 0.5 and salted-out above this ionic strength.

$\mathrm{NaCl}$ effect on plastein formation by a salttolerant protease

Neutral Protease II whose activity was not affected by salt was used to produce a plastein at various $\mathrm{NaCl}$ concentrations and this study 


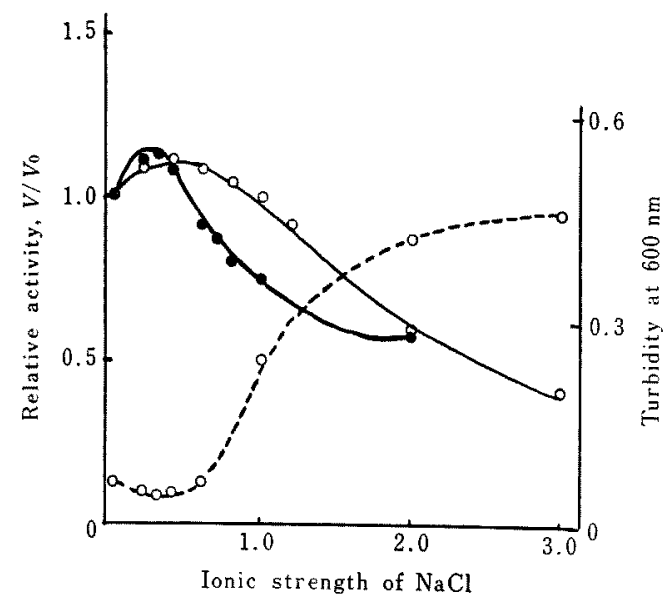

FIG. 2. Effects of $\mathrm{NaCl}$ upon the Hydrolytic Activity of $\alpha$-Chymotrypsin toward $N$-Acetyl-L-tyrosine Ethyl Ester $(\mathrm{O}-\mathrm{O})$ and toward $N$-Benzyloxycarbonyl-Lphenylalanine $p$-Nitrophenyl Ester (-) and upon the Insolubilization of this Enzyme (O---O).

To $0.01 \mathrm{M}$ phosphate (pH 7.8) containing $5 \% \mathrm{CH}_{3} \mathrm{CN}$ and a given concentration of $\mathrm{NaCl}$, was dissolved ATEE to a concentration of $2 \mathrm{~mm}$. a-Chymotrypsin was dissolved in deionized water to a concentration of $5 \times 10^{-7} \mathrm{M}$. A $1: 10$ mixture of both solutions was incubated at $18^{\circ} \mathrm{C}$ for $4 \mathrm{~min}$ and the ATEE hydrolysis followed by measuring a decrease in optical density at $237 \mathrm{~nm}$.

The desalted protein hydrolysate $(350 \mathrm{mg})$ was dissolved in deionized water $(0.9 \mathrm{ml})$ containing $5 \%$ $\mathrm{CH}_{3} \mathrm{CN}$ and a given concentration of $\mathrm{NaCl}$. To this solution was dissolved Z-Phe-PNP to a concentration of $0.2 \mathrm{~mm}$. $\quad \alpha$-Chymotrypsin $(0.1 \mathrm{mg})$ was dissolved in deionized water $(1 \mathrm{ml})$. A 1:9 mixture of both solutions was incubated at $18^{\circ} \mathrm{C}$ for $15 \mathrm{~min}$. The reaction was stopped by adding $4 \mathrm{ml}$ of $0.1 \mathrm{~N} \mathrm{HCl}$. The liberated PNP was extracted with $10 \mathrm{ml}$ of $\mathrm{CH}_{3} \mathrm{Cl}$ ether (4: 1). After evaporating the solvent, the residue was dissolved in $2.0 \mathrm{ml}$ of $0.1 \mathrm{M}$ phosphate ( $\mathrm{pH} 7.8$ ) and the optical density measured at $402 \mathrm{~nm}$.

$a$-Chymotrypsin $(5 \mathrm{mg}$ ) was added to an $\mathrm{NaCl}$ solution $(1 \mathrm{ml})$ having a given ionic strength and the resulting turbidity was measured at $600 \mathrm{~nm}$.

gave a result shown in Fig. 4. The productivity increased with the $\mathrm{NaCl}$ concentration and doubled at $3 \mathrm{M}$.

\section{DISCUSSION}

Chymotryptic plastein formation was changeable in accordance with the lyotropic series of salts. Mono-monovalent salts generally enhanced the plastein formation (Table I). Therefore we picked out $\mathrm{NaCl}$ as a represen-

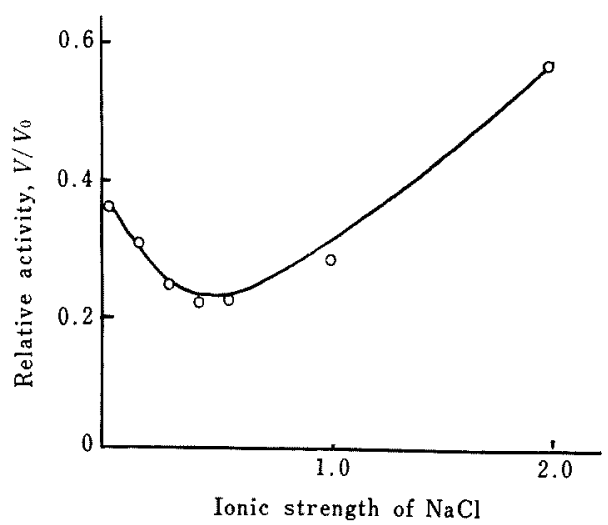

FIG. 3. Effect of $\mathrm{NaCl}$ on Solubility of a Plastein.

A plastein $(25 \mathrm{mg}$ ) was added to an $\mathrm{NaCl}$ solution $(5 \mathrm{ml})$ having a given ionic strength and the resulting turbidity was measured at $600 \mathrm{~nm}$.

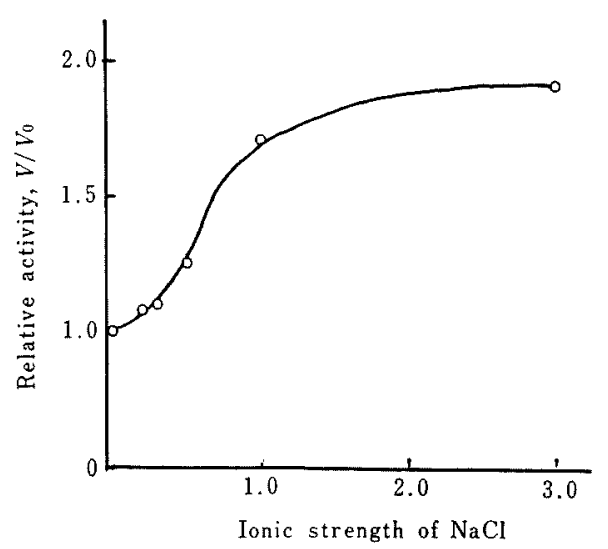

FIG. 4. Effect of $\mathrm{NaCl}$ on the Plastein Formation by a Salt-tolerant Protease.

tative and investigated the plastein formation as a function of $\mathrm{NaCl}$ concentration. We observed the two maximal plastein yields at ionic strength 0.1 and 0.8 (Fig. 1). In order to make clear this phenomenon, the $\mathrm{NaCl}$ effect on hydrolytic activity of the enzyme was investigated. As shown in Fig. 2, only one maximum was observed at ionic strength 0.2 . This fact suggests that the first maximum results from an increase in the enzyme activity. Similar phenomena have been reported in the case of carboxypeptidase $\mathrm{A}^{11)}$ and glutamate dehydrogenase..$^{21}$

The second maximum was observed at a higher ionic strength resion where many 
proteins were easily salted-out. ${ }^{13)}$ The plastein reaction product was salted-in below an ionic strength of about 0.5 and salted-out above this ionic strength (Fig. 3). But the salting-out may happen at lower ionic strength in plastein synthesis by reason the concentration of substrate was 70 times higher as compared with this experimental condition. From this result the second maximum is ascribable to the salting-out of the product due to the higher concentration of $\mathrm{NaCl}$.

A salt-torelant proteinase from Aspergillus sojae (neutral protease II) was also used to obtain a further positive proof. As expected, a higher $\mathrm{NaCl}$ concentration was much more favorable in plastein synthesis than hydrolysis (Fig. 4). This may have practical use in producing a plastein more efficiently by using salt torelant enzymes.

Acknowledgement. We express our thanks to $\mathrm{Mr}$. H. Sekine, Noda Institute for Research, for supplying a salt-tolerant protease used in this investigation.

\section{REFERENCES}

1) S. Tanimoto, M. Yamashita, S. Arai and M.
Fujimaki, Agr. Biol. Chem., 36, 1595 (1972).

2) M. Yamashita, S. Arai, S. Tanimoto and M. Fujimaki, Biochim. Biophys. Acta, 358, 105 (1974).

3) M. Yamashita, S. Arai, J. Matsuyama, M. Gonda, H. Kato and M. Fujimaki, Agr. Biol. Chem., 34, 1484 (1970).

4) S. -J. Tsai, M. Yamashita, S. Arai and M. Fujimaki, ibid., 38, 641 (1974).

5) S.-J. Tsai, M. Yamashita, S. Arai and M. Fujimaki, ibid., 36, 1045 (1972).

6) M. Yamashita, S.-J. Tsai, S. Arai, H. Kato and M. Fujimaki, ibid., 35, 86 (1971).

7) M. Bodanszky and V. D. Vigneaud, J. Am. Chem. Soc., 81, 5688 (1959).

8) H. Sekine, Abstracts of Papers, Annual Meeting of the Kanto Branch of the Agricultural Chemical Society of Japan, Niigata, Oct., 1973, p. 2.

9) G. W. Schwert and Y. Takenaka, Biochem. Biophys. Acta, 16, 570 (1955).

10) M.S. Silver and M.S. Matta, Arch. Biochem. Biophys., 151, 62 (1972).

11) R. Lumry, E. L. Smith and R. R. Glants, J. Am. Chem. Soc., 73, 4330 (1951).

12) L. Corman and N. O. Kaplan, J. Biol. Chem., 242, 2840 (1967).

13) C. W. Davis, "Progress in Reaction Kinetics," ed. by G. Porter, Pergamon Press, 1961, p. 161. 